\title{
Small Scale Determinations for Biogas Production Using Anaerobic Fermentation - 2L Batch Scenarios
}

\author{
LUISA IZABEL DUNGAN ${ }^{1}$, ADRIAN EUGEN CIOABLĂ ${ }^{1 *}$, VASILE PODE ${ }^{2}$ \\ ${ }^{1}$ University Politehnica of Timisoara, Mechanical Engineering Faculty, 1 Mihai Viteazu Blvd., 300222, Timisoara, \\ Romania \\ ${ }^{2}$ University Politehnica of Timisoara, Faculty of Industrial Chemistry and Environmental Engineering, 6 Vasile Parvan \\ Blvd., 300223, Timisoara, Romania
}

\begin{abstract}
Nowadays demand for clean energy and new solutions for renewable energy carriers makes it a challenge to find new substrates that can be used for production of biofuels. In this context the present paper aims to present possible solutions of substrate mixtures using materials that exist in abundance at least in the western part of Romania. Conclusions will be traced relative to material potential at small scale in terms of producing biogas.
\end{abstract}

Keywords: anaerobic fermentation, biogas, residual materials

Wastewater treatment is facing serious problems worldwide due to environment concerns regarding resource shortage. Moreover, the economic world is pressured by the environment researchers to find new sustainable solutions for green energy production [1]. As a result, a keen interest is being devoted to renewable feed stocks based on organic/inorganic used materials which can be turned into (bio)fuels [2].

Anaerobic digestion process has been identified as a low energy consumption technology for efficient recovery of wastewater (with/without organic substrate) as biogas [3-5]. Anaerobic digestion is a promising technology applied to treat different types of organic wastes and to reduce their biodegradability while recovering bio-energy [6,7]. By anaerobic digestion, organic carbon is converted by redox reactions into its most oxidized state $\left(\mathrm{CO}_{2}\right)$ and its most reduced state $\left(\mathrm{CH}_{4}\right)$ [8]. It is a complex process consisting of several stages: hydrolysis, acidification, acetate synthesis and methanogenesis [9]. Hydrolysis is considered the rate determining step involved in this process and it can be controlled by suitable adjustment of the organic substrate particle size, temperature, $\mathrm{pH}$, homogeneity, etc [10]. The acidification bacteria then turn soluble organic material into organic acids, carbon dioxide and hydrogen during the acidification step. The organic acids are decomposed into acetic acid/esters, formic acid/esters which are transformed into methane by methanogenic microorganisms [11]. Moreover, the digestate, meaning the effluent coming out of the anaerobic process can be reused in agriculture as nutrient for plants because of its high $\mathrm{N}, \mathrm{P}, \mathrm{K}$ content together with humic substances [12].

This multi-step complex process can be successful only in the presence of the right bacteria consortia, temperature and $\mathrm{pH}$ control and organic matter able to produce significant amounts of methane. The anaerobic fermentation can occur in mesophilic and thermophilic environment. Compared to the mesophilic temperature, the thermophilic process has the advantage of the greater methane yield, lower retention time but it has the draw-back of inhibition substances accumulation which terminates the methanogenesis [13].

The substrate of the anaerobic digestion is also a determining performance item. Usually for the improvement of the methane yields, co-digestion in anaerobic conditions of a main basic feedstock (e.g. animal manure, waste water, sewage sludge, etc.) mixed with a secondary feedstock (e.g. crop residue, food or silage wastes) is fed into the digestion reactor with or without an incoculum (bacteria) [14].

Our research group has focused on the anaerobic digestion of mixed substrate, waste water and cereal wastes, in mesophilic conditions following a batch reactor approach at pilot-scale [15-18]. The environmental impact of using waste water as co-substrate for anaerobic digestion through which a useful resource is produced represents a promising alternative for future economic development [18-24].

The papers will present small scale determinations of different substrates in order to determine the suitable ones for further testing at larger scale.

\section{Experimental part}

Experimental setup

For experimental purposes, it was used a thermostatic bath and batches of $1.5 \mathrm{~L}$ inside of plastic vessels with a total volume of $2 \mathrm{~L}$. The work principle of the small scale testing rig is presented below.

*email: adrian.cioabla@upt.ro 


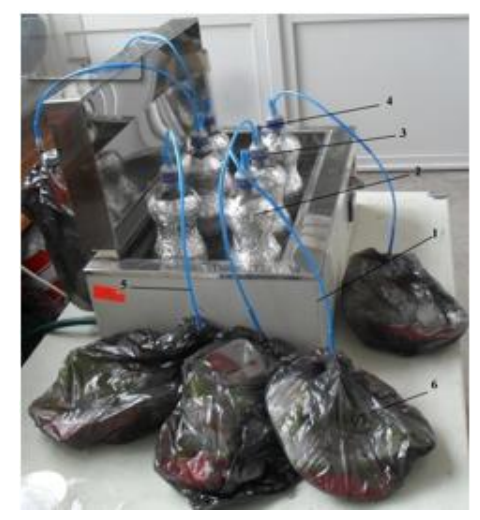

Fig. 1. Overall view of the test rig

The components are described as follows:

1 - thermostatic bath with multiple places for heating up the used materials for the anaerobic fermentation process (the temperature is controlled with the help of the thermocouple and can be checked with the help of a thermometer inserted into the bath);

2 - plastic bottles with a total volume of $2 \mathrm{~L}$, filled up to about $1.5 \mathrm{~L}$ with the materials used for determinations;

3 - the corks of the plastic bottles were modified in order to allow both sampling for $\mathrm{pH}$ checking, homogenization by means of plastic syringes, and gas transfer from the bottles into the gas bags. Also, because of the light sensibility of the anaerobic bacteria, the bottles were covered with aluminum foil;

4 - hose orifice for syringe insertion, used for sampling and homogenization;

5 - connection (small diameter hose) between the plastic bottle and the gas bag for biogas storage;

6 - gas bag for biogas storage.

Substrate choices and general informations regarding the used materials.

The general properties of the used materials for the batches at $2 \mathrm{~L}$ are presented below. The determinations were made according to standard methods [26-30].

Table 1

GENERAL CHARACTERISTICS OF THE USED MATERIALS (PART 1)

\begin{tabular}{|c|c|c|c|c|}
\hline No. & MATERIAL & $\begin{array}{c}\text { Higroscopic } \\
\text { Moisture } \\
\text { content } \\
{[\%]}\end{array}$ & $\begin{array}{c}\text { Ash content } \\
\text { (dry basis) } \\
{[\%]}\end{array}$ & $\begin{array}{c}\text { Mean calorific value } \\
\text { (dry basis) } \\
{[\mathrm{MJ} / \mathrm{kg}]}\end{array}$ \\
\hline 1. & $\begin{array}{l}\text { DBZ5 (digestate, cow manure } \\
\text { and 5\% cow whey) }\end{array}$ & 13 & 25 & 14.2 \\
\hline 2. & $\begin{array}{l}\text { DBZ10 (digestate, cow manure } \\
\text { and } 10 \% \text { cow whey) }\end{array}$ & 14.3 & 25.1 & 14 \\
\hline 3. & $\begin{array}{c}\text { UEN5Z5(waste water from } \\
\text { treatment plant, 5\% stabilized } \\
\text { sludge from treatment plant, } \\
5 \% \text { cow whey }\end{array}$ & 5.8 & 38.1 & 14.8 \\
\hline 4. & $\begin{array}{l}\text { UEN4Z5(waste water from } \\
\text { treatment plant, } 4 \% \text { stabilized } \\
\text { sludge from treatment plant, } \\
5 \% \text { cow whey) }\end{array}$ & 5.9 & 38 & 14.7 \\
\hline 5. & $\begin{array}{c}\text { FBN5Z5(waste water from } \\
\text { beer factory, 5\% stabilized } \\
\text { sludge from treatment plant, } \\
5 \% \text { cow whey) }\end{array}$ & 5.4 & 28 & 17 \\
\hline 6. & $\begin{array}{l}\text { FBN4Z5 (waste water from } \\
\text { beer factory, } 4 \% \text { stabilized } \\
\text { sludge from treatment plant, } \\
5 \% \text { cow whey) }\end{array}$ & 5.5 & 28.2 & 17.5 \\
\hline
\end{tabular}


Table 2

GENERAL CHARACTERISTICS OF THE USED MATERIALS (PART 2)

\begin{tabular}{|c|c|c|c|c|}
\hline No. & MATERIAL & $\begin{array}{c}\text { Carbon } \\
\text { content } \\
{[\%]}\end{array}$ & $\begin{array}{c}\text { Sulphur } \\
\text { content } \\
{[\%]}\end{array}$ & $\begin{array}{c}\text { Volatile } \\
\text { content } \\
\text { (dry basis) } \\
{[\%]}\end{array}$ \\
\hline 1. & $\begin{array}{c}\text { DBZ5 (digestate, cow manure } \\
\text { and 5\% cow whey) }\end{array}$ & 29.5 & 0.5 & 43 \\
\hline 2. & $\begin{array}{c}\text { DBZ10 (digestate, cow manure } \\
\text { and 10\% cow why) }\end{array}$ & 29 & 0.6 & 48.5 \\
\hline 3. & $\begin{array}{c}\text { UEN5Z5(waste water from } \\
\text { treatment plant, 5\% stabilized } \\
\text { sludge from treatment plant, } \\
5 \% \text { cow whey }\end{array}$ & 33.7 & 5.2 & 38.6 \\
\hline 4. & $\begin{array}{c}\text { UEN4Z5(waste water from } \\
\text { treatment plant, 4\% stabilized } \\
\text { sludge from treatment plant, } \\
5 \% \text { cow whey) }\end{array}$ & 33 & 4.8 & 38.2 \\
\hline 5. & $\begin{array}{c}\text { FBN5Z5(waste water from } \\
\text { beer factory, 5\% stabilized } \\
\text { sludge from treatment plant, } \\
5 \% \text { cow whey) }\end{array}$ & 36.1 & 3.9 & 40.6 \\
\hline 6. & $\begin{array}{c}\text { FBN4Z5 (waste water from } \\
\text { beer factory, 4\% stabilized } \\
\text { sludge from treatment plant, } \\
5 \% \text { cow whey) }\end{array}$ & 36 & 4 & 40.4 \\
\hline
\end{tabular}

From the tables above it can be observed that the ash content is high making the materials unsuitable for firing processes as standalone fuel, while the calorific value is relatively high, indicating a good energetic potential for the chosen batches. The sulphur content is high for the last 3 batches, being a potential problem for the firing chamber in case of firing processes.

\section{Results and discussions}

The $\mathrm{pH}$ of the suspension was corrected with a solution of $\mathrm{NH}_{3} 20 \%$ concentration and the temperature regime was held inside the domain of $36-37^{\circ} \mathrm{C}$. The experiment lasted for 45 days of continuous measurements.

The time variation for $\mathrm{pH}$ is presented below.

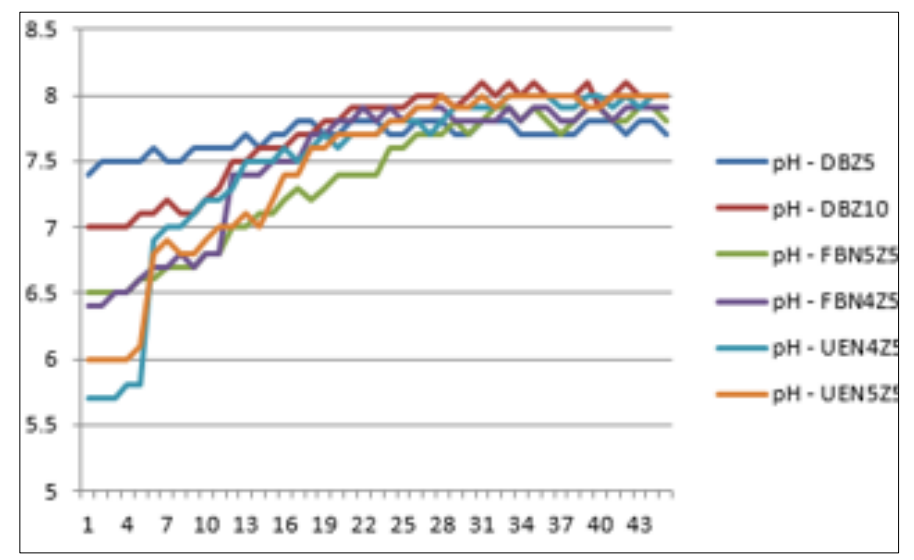

Fig. 2. $p \mathrm{H}$ variation for the studied batches of material

It can be observed that during the process, the starting $\mathrm{pH}$ values are relatively high, about $5.7-6$, and the general correcting operations were reduced to a minimum because of the buffer capacity for the tested batches of material. The final $\mathrm{pH}$ values at the end of the process are $7.5-8$, suitable for the anaerobic fermentation conditions.

For gas analyzing there was used the DELTA 1600 S IV gas analyzer, which allows determination of methane and carbon dioxide composition up to $100 \%$ by volume.

All the six batches produced biogas, and the final measured composition is:

$\begin{array}{ll}\text { For DBZ5 batch }- & \mathrm{CH}_{4} \text { conc. }=57 \% \\ & \mathrm{CO}_{2} \text { conc. }=41 \% \\ \text { For DBZ10 batch }- & \mathrm{CH}_{4} \text { conc. }=53 \% \\ & \mathrm{CO}_{2} \text { conc. }=42 \% \\ \text { For FBN5Z5 batch }- & \mathrm{CH}_{4} \text { conc. }=68 \% \\ & \mathrm{CO}_{2} \text { conc. }=27 \%\end{array}$


Unfortunately, the other two batches (UEN5Z5 and UEN4Z5) did not produce any biogas, proving to be not suited for anaerobic fermentation processes at first tests.

The produced quantities were about $9.5 \mathrm{~L}$ of gas for the DBZ5, 11L for DBZ10, 8L for FBN5Z5 and 3.5 for FBN4Z5 batch.

\section{Conclusions}

The present paper aimed to present a small scale approach in terms of biogas production using different material combinations and evaluated partially the biogas quantity and quality.

From the obtained results it can be deduced that the most suitable materials, at leat in the presented scenario, were the batched containing waste water from beer factory, 5\% stabilized sludge from treatment plant, 5\% cow whey and waste water from beer factory, $4 \%$ stabilized sludge from treatment plant, $5 \%$ cow whey.

It seems that the waste water from beer factory proves to be a more reliable substrate than the one from the treatment plant because of its general composition and bacteria existing in it.

\section{References}

1.ERIKSSON O., BISAILLON M., HARALDSSON M., SUNDBERG J., Enhancement of biogas production from food waste and sewage sludge - Enviromental and economic life cycle performance, Journal of Environmental Management, 175, 2016, p. 33-39

2.LEI Z., YANG S., LI Y., WEN W., WANG X.C., CHEN R., Application of anaerobic membrane bioreactors to municipal wastewater treatment at ambient temperature: A review of achievements, challenges, and perspectives, Bioresource Technology 267, 2018, p. 756-768

3.ZHOU J., YANG J., YU Q., YONG X., XIE X., ZHANG L., WEI P., JIA H., Different organic loading rates on the biogas production during the anaerobic digestion of rice straw: A pilot study, Bioresource Technology, 244, 2017, p. 865-871

4.DE CLERCQ D., WEN Z., CAICEDO L., CAO X., FAN F., XU R., Application of DEA and statistical inference to model the determinants of biomethane production efficiency: A case study in south China, Applied Energy, 205, 2017, p. 1231-1243

5.RUSIN J., KASAKOVA K., CHAMRADOVA K., Anaerobic digestion of waste wafer materials from the confectionary production, Energy, 85, 2015, p. 194-199

6.MICOLUCCI F., GOTTARDO M., CAVINATO C., PAVAN P., BOLZONELLA D., Mesophilic and thermophilic anaerobic digestion of the liquid fraction of pressed biowaste for high energy yields recovery, Waste Management, 48, 2016, p. 227-235

7.DI MARIA F., SEGOLONI E., PEZZOLLA D., Solid anaerobic digestion batch bio-waste as pre-treatment for improving amendment quality: The effect of inoculum recirculation, Waste Management, 56, 2016, p. 106-112

8.MICOLUCCI F., GOTTARDO M., MALAMIS D., BOLZONELlA D., PAVAN P., CECCHI F., Analysis of Meso/Thermo AD Process applied to pressed biowaste, Waste Biomass Valor 6, 2015, p. 723-731

9.PETRACCHINI F., LIOTTA F., PAOLINI V., PERILLI M., CERIONI D., GALLUCCCI F., CARNEVALE M., BENCINI A., A novel polit scale multistage semidry anaerobic digestion reactor to treat food waste and cow manure, Int. J. Environ. Sci. technol., 2018, 15: p. 1999-2008,

10.GAO X., LIU X., WANG W., Biodegradation of particulate organics and its enhancement during anaerobic co-digestion of municipal biowaste and wate activated sludge, Renewable Energy, 96, 2016, p. 1086-1092

11.TONANZI B., GALLIPOLI A., GIANICO A., MONTECCHIO D., PAGLIACCIA P., DI CARLO M., ROSSETTI S., BRAGUGLIA C.M., Long-term anaerobic digestion of food waste at semi-pilot scale: Relationship between microbial community structure and process performances, Biomass and Bioenergy, 118, 2018, p. 55-64

12.DA ROS C., CAVINATO C., PAVAN P., BOLZONELLA D., Mesophilic and thermophilic anaerobic co-digestion of winery wastewater sludge and wine lees: An integrated approach for sustainable wine production, Journal of Environmental Management, 203, 2017, 745-752,

13.FENG L., WARD A.J., GUIXE P.G., MODET V., MOELLER H.B., Flexible biogas production by pulse feeding maize silage or briquetted meadow grass into continuous stirred tank reactors, Biosystems Engineering, 174, 2018, p. 1-10

14.VALENTI F., PORTO S.M.C., SELVAGGI R., PECORINO B., Evaluation of biomethane potential from by-products and agricultural residues co-digestion in southern Italy, Journal of Environmental Management, 223, 2018, p. 834-840

15.CIOABLA A.E., IONEL I., DUMITREL G.A., NEGREA P., PODE V., Biogas production through anaerobic digestion of some agroindustrial residues, Rev. Chim. (Bucharest), 63, no. 6, 2012, p. 629-632

16.DUMITREL G.A., CIOABLA A.E., IONEL I., VARGA L.A., Experimental and Modelling Approach of Biogas Production by anaerobic digestion of agricultural resources, Rev. Chim. (Bucharest), 68, no. 6, 2017, p.1294-1297

17.CIOABLA A.E., DUMITREL G.A., IONEL I., Evaluation by kinetic models of anaerobic digestion performances for various substrates and co-substrates, Rev. Chim. (Bucharest), 68, no. 1, 2017, p. 2614-2617

18.NEAMT I., IONEL I., Efficiency assessment of the anaerobic digestion of sewage sludge from Timisoara minicipal water treatment plant, Rev. Chim. (Bucharest), 65, no. 9, 2014, p. 1117-1121

19.VARGA L., CIOABLA A.E., IONEL I., Comparative determination of cofermentation using residual waters for biogas production at small scale, Rev. Chim. (Bucharest), 67, no. 1, 2016, p.174-176,

20.CIOABLA A.E., DUMITREL G.A., POPESCU F., LELEA D., TRIF-TORDAI G., Biogas production using residual waters in cofermentation processes, Materials Today: Proceedings, 4(7), 2017, p. 6757-6763

21.NEAMT I., IONEL I., FLORESCU C., Sewage sludge to energy. Possible strategies for Timisoara water treatment plant, Rev. Chim. (Bucharest), 63, no. 7, 2012, p.739-742

22.CIOABLA A.E., IONEL I., DUMITREL G.A., POPESCU F., Comparative study on factors affecting anaerobic digestion of agricultural vegetal residues, Biotechnology for Biofuels, 5, 2012, p. 39

23.CIOABLA A.E., POPESCU F., TRIF-TORDAI G., DUMITREL G.A., OPRISA-STANESCU P.D., LELEA D., Sustainable development of Romanian cities through biogas production from municipal wastes and application in co-combustion processes, Thermal Science, 2018, 22(2), p. 1071-1076 
24.CIOABLA A.E., IONEL I., TENCHEA A., DUMITREL G.A., PODE V., Solid biofuel database - Potential of using Vegetal Biomass in biogas production, Rev. Chim. (Bucharest), 64, no. 2, 2013, p. 186-190

25.***EN 14774 - Solid biofuels - Determination of moisture content - Oven dry method

26.***EN 14775 - Solid biofuels - Determination of ash content

27.***EN 14918 - Solid biofuels - Determination of calorific value

28.***EN 15290 - Solid biofuels - Determination of major elements

29.***EN 15104 - Solid biofuels - Determination of total content of carbon, hydrogen and nitrogen

30.***EN 15148 - Solid biofuels - Determination of the content of volatile matter

Manuscript received: 18.10 .2018 